\title{
Typing of strains of Staphylococcus aureus by Western Blot analysis of culture supernates
}

\author{
S. J. KRIKLER, T. H. PENNINGTON and DIANE PETRIE
}

\begin{abstract}
Department of Bacteriology, University of Aberdeen, University Medical Buildings, Foresterhill, Aberdeen AB9 2ZD
\end{abstract}

\begin{abstract}
Summary. Extracellular proteins produced by Staphylococcus aureus strains were examined by Western Blot analysis with blood donor plasma as a source of antibodies. Comparison of epidemiologically related strains showed strong concordance between plot pattern and phage type.
\end{abstract}

\section{Introduction}

Bacteriophage typing of Staphylococcus aureus isolates is a valuable tool in the study of staphylococcal disease in man (Parker, 1983). The occurrence of a significant number of non-typable strains, and uncertainties arising from the knowledge that changes in the susceptibility to bacteriophages may be brought about by lysogenization (Rountree, 1959), make alternative typing methods desirable. Serotyping schemes based on surface antigens have been developed and as many as 30 antigenic factors can be recognised (Oeding, 1978).

Polyacrylamide-gel electrophoresis (PAGE) of bacterial proteins has been used extensively as a taxonomic tool, and, more recently, for typing (Poxton et al., 1984; Tabaqchali et al., 1984). Sacks et al. (1969) used PAGE of cell proteins to classify Enterobacteriaceae; they included $S$. aureus in their study and showed that the polypeptide profiles of this organism were very different from those of the Enterobacteriaceae examined.

In this study we have compared different strains of $S$. aureus by PAGE of whole cell extracts, and by Western blotting of extracellular proteins with human plasma as a source of anti-staphylococcal antibodies.

\section{Materials and methods}

\section{S. aureus strains}

S. aureus strains were obtained from nasal swabs from a group of men living in complete isolation for a year in Antarctica. Isolates from six subjects were used in this study. They were isolated from swabs taken over a period of $c 40$ weeks. The table shows details of the strains. They were identified as $S$. aureus in Antarctica by colonial

Received 29 May 1985; accepted 21 Jun. 1985. morphology, Gram's stain and coagulase testing. Cultures were stored on nutrient-agar slopes in $1-\mathrm{ml} \mathrm{screw-}$ capped bottles held at $4^{\circ} \mathrm{C}$ until the cultures were revived at the Staphylococcal Reference Laboratory, Colindale, where phage typing was performed. Fresh storage cultures were prepared as before, and transferred to the Department of Bacteriology, University of Aberdeen for further analysis.

\section{Preparation of material for electrophoresis}

In Aberdeen the organisms were plated out on nutrient agar plates which were then incubated at $37^{\circ} \mathrm{C}$ for $24 \mathrm{~h}$. A sweep of colonies from these plates was inoculated into 10 $\mathrm{ml}$ of nutrient broth in a $20-\mathrm{ml}$ screw-capped container which was incubated overnight at $37^{\circ} \mathrm{C}$ with shaking in an orbital incubator. The resulting broth culture was centrifuged at $2500 \mathrm{~g}$ for $15 \mathrm{~min}$ and the upper $2 \mathrm{ml}$ of the supernate removed for gel analysis. The remainder of the supernate was discarded and a concentrated suspension of the cell pellet placed in a Microfuge (Beckman B) tube and centrifuged for $5 \mathrm{~min}$. The pellet thus produced was washed in an equal volume of distilled water and disrupted for $5 \mathrm{~min}$ with an ultrasound probe (Rapidis 150 , Ultrasonics Ltd, Shipley, W. Yorks) emitting $45 \mathrm{~W}$ at maximum power. Protein concentrations were estimated by the method of Bradford (1976).

\section{Polyacrylamide-gel electrophoresis (PAGE)}

A modified version of the SDS-PAGE technique of Laemmli (1970) was used. Specimens were prepared for PAGE by boiling for $5 \mathrm{~min}$ in sodium dodecyl sulphate (SDS) $2 \% \mathrm{w} / \mathrm{v}, 2$-mercaptoethanol $5 \% \mathrm{v} / \mathrm{v}$, glycerol $10 \%$ $\mathrm{v} / \mathrm{v}$ and $0.05 \mathrm{M}$ Tris- $\mathrm{HCl}, p \mathrm{H} \mathrm{6.8}$. They were applied to wells in a $3.6 \%$ acrylamide stacking gel over a separating gel of $10 \%$ acrylamide. Gels were run in a Mk 1 Protein Cell (Bio-Rad) at $60 \mathrm{~mA}$, with the buffers described by Laemmli, until the bromophenol blue marker had reached the bottom of the gel; this occurred after c. $660 \mathrm{~V}$ h. Proteins were either stained with Coomassie Blue or transferred to nitrocellulose paper. 
Table Phage types of isolates from each subject

\begin{tabular}{|c|c|c|c|}
\hline \multirow[b]{2}{*}{ Subject } & \multicolumn{3}{|c|}{ Phage typing results } \\
\hline & RTD & $100 \times$ RTD & $\begin{array}{l}\text { Experimental } \\
\text { phages }\end{array}$ \\
\hline 9 & $94 / 96$ & $94 / 96$ & $47 \mathrm{~A} / 27 / 33$ \\
\hline 12 & 94/96 & $94 / 96$ & \\
\hline 16 & $29 / 52+$ & $29 / 52 / 80 / 81+$ & \\
\hline 21 & NT & $83 \mathrm{~A} / 85+$ & $90 / 932$ \\
\hline 23 & $6 / 47 / 53 / 54$ & $\begin{array}{l}6 / 47 / 53 / 54 / 75 / 77 \\
83 \mathrm{~A} / 84 / 85 / 81\end{array}$ & 88A90/932 \\
\hline 28 & NT & $29 / 47 / 54 / 75 / 77 / 85 / 81$ & \\
\hline
\end{tabular}

\section{Blotting}

Transfer of proteins was achieved by the technique of Towbin et al. (1979), with Burnette's (1981) addition of filter paper to the sandwich and with a Bio-Rad Transblot cell. Transfer was effected overnight at $70 \mathrm{~mA}$, with the buffer described by Burnette. The paper was washed in

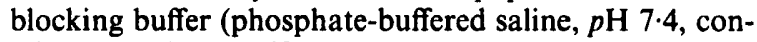
taining newborn calf serum $10 \% \mathrm{v} / \mathrm{v}$ ) and Triton $\mathrm{x}-100$ $0.2 \% \mathrm{v} / \mathrm{v}$ for $30 \mathrm{~min}$, followed by treatment with human plasma diluted 1 in 50 in blocking buffer for $1 \mathrm{~h}$. Preliminary study by Western Blot analysis of whole-cell extracts had shown that plasma from this donor contained antibodies against a large number of staphylococcal polypeptides. The paper was then washed three times for $15 \mathrm{~min}$ each in blocking buffer followed by $45 \mathrm{~min}$ in a solution of peroxidase-linked goat anti-human serum (Miles-Yeda, Israel) diluted 1 in 500. It was then washed another three times for 15 min each in blocking buffer, rinsed in phosphate-buffered-saline and stained with diamino-benzidine tetrahydrochloride $0.05 \% \mathrm{w} / \mathrm{v}$ in $0.1 \mathrm{M}$ Tris $(p \mathrm{H} \mathrm{7.6)}$ containing hydrogen peroxide $0.01 \% \mathrm{v} / \mathrm{v}$.

\section{Results}

Figs. A and B show the results obtained with isolates from six subjects. Fig. A shows a polyacrylamide gel, stained with Coomassie Blue, showing the results obtained with whole-cell extracts. Apart from the absence of a single protein band in tracks $\mathrm{N}, \mathrm{O}$ and $\mathrm{P}$, all the isolates were virtually indistinguishable. Fig. 1B shows a Western Blot of supernate from the same isolates in the same order as fig. A. The isolates from five individuals can be grouped according to their pattern of bands, isolates from an individual resembled each other closely, and isolates from different individuals were easily distinguished from each other. The only exception to this was with the isolates from subjects 9 and 12 which were indistinguishable. Isolates were grouped after visual inspection of Western-Blotband patterns and on the basis of (i) possession of bands unique to a group, (ii) band intensity, and (iii) the presence or absence of bands common to several groups. Comparison of grouping by Western-Blotband pattern and phage-typing results showed complete concordance (table); isolates from subjects 16, 21, 23 and 28 were distinguishable from
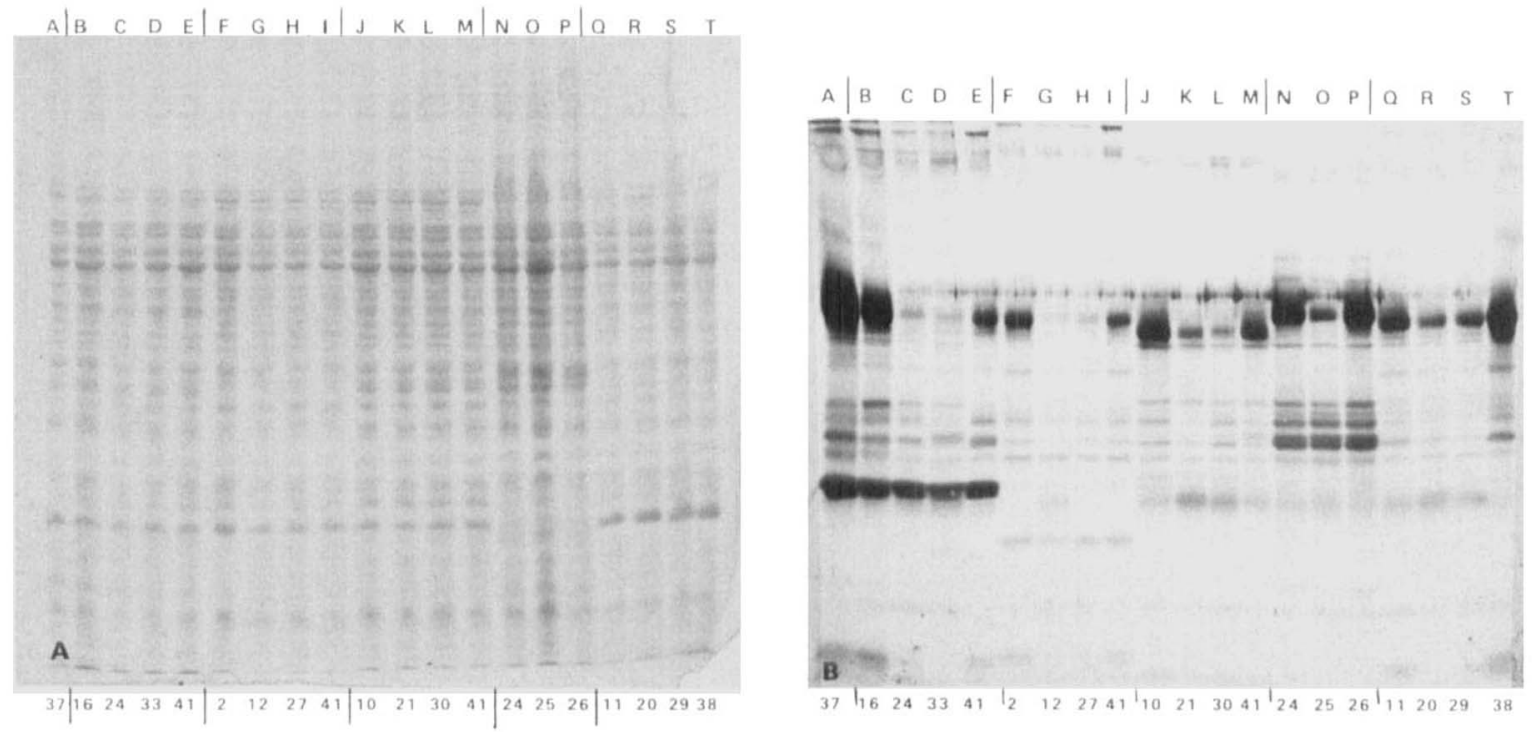

Figure (A) Polyacrylamide-gel electropherogram of whole-cell extracts, stained with Coomassie Blue. (B) Western Blot analysis of culture supernatants from the same strains. Track $A$, isolate from subject 9 ; tracks $B-E$, isolates from subject 12; tracks $F-I$ isolates from subject 16 ; tracks $J-M$, isolates from subject 21 ; tracks $N-P$, isolates from subject 23 , tracks $Q-T$, isolates from subject 28. Numbers refer to the week on which the isolate was obtained. 
each other and from the isolates from subjects 9 and 12 , whereas strains from the latter pair of subjects could not be distinguished from each other either by Western-blot-band pattern or with the phages in the International Basic Set. The pattern produced by a particular strain isolated repeatedly from a subject was constant over a period of several months and did not change after 10 subcultures in the laboratory (results not shown).

\section{Discussion}

Each of the six subjects in this study carried a $S$. aureus of different phage type throughout the year. The phage types are shown in the table. Because the subjects were in total isolation and under intensive microbiological surveillance throughout the period during which the samples were obtained it is felt that strains obtained were particularly suitable epidemiologically for a study of this nature. The Western Blots clearly show that isolates from a single individual produced very similar bands, whereas, with the exception of the strains from subjects 9 and 12, isolates from different individuals produced different patterns. As a typing technique, this method appears to be comparable in reproducibility to phage typing and it is interesting to note the similarity between the two strains of phage-group $\mathrm{V}$ (subjects 9 and 12).

The whole-cell-protein profiles in Coomassie

\section{REFERENCES}

Bradford M M 1976 A rapid and sensitive method for the quantitation of microgram quantities of protein utilising the principle of protein-dye binding. Analytical Biochemistry 72:248-254.

Burnette W N 1981 "Western Blotting": electrophoretic transfer of proteins from sodium dodecyl sulphate-polyacrylamide gels to unmodified nitrocellulose and radiographic detection with antibody and radioiodinated protein A. Analytical Biochemistry 112:195-203.

Laemmli U K 1970 Cleavage of structural proteins during the assembly of the head of bacteriophage T4. Nature 227:680685 .

Oeding P 1978 Genus Staphylococcus. In: Bergan T, Norris J R (ed) Methods in Microbiology Volume 12. Academic Press, London p 127-176.

Parker M T 1983 Staphylococcus and Micrococcus. The anaerobic gram-positive cocci. In: Wilson G S, Miles A A, Parker M T, (eds) Topley and Wilson's Principles of bacteriology,
Blue-stained gels were very similar and the majority of isolates were virtually indistinguishable.

This study was limited to strains from healthy individuals without clinical manifestations of staphylococcal infection during the study. We plan to study the extracellular products of strains associated with clinical infection.

Analysis by Western blotting was chosen because it allows detection of products present in amounts too small to be detected by conventional staining methods and because the identification and characterisation of extracellular products which elicit antibodies in human subjects may be of value in furthering an understanding of the pathogenesis of staphylococcal infections.

By obtaining a time-expired donation of plasma from the Blood Transfusion Service, sufficient material for many typing studies was ensured, particularly in view of the 1 in 50 working dilution used. Further studies are in progress in which Western-blot patterns shown by other human sera are being compared to allow an assessment of the general usefulness of such an antibody source for typing staphylococci with this method.

We thank the British Antarctic Survey for their financial support, all the subjects for their cooperation in supplying the organisms studied, the Department of Medical Illustration for their help in preparing the figures, and the Director, N E Scotland Blood Transfusion Service for providing plasma.

virology and immunity, 7th edn, vol. 2. Chapter 2. Edward Arnold, London. pp 218-245.

Poxton I R, Aronsson B, Möllby R, Nord C E, Collee J G 1984 Immunochemical fingerprinting of Clostridium difficile strains isolated from an outbreak of antibiotic-associated colitis and diarrhoea. Journal of Medical Microbiology 17:317-324.

Rountree P M 1959 Changes in the phage-typing patterns of staphylococci following lysogenization. Journal of General Microbiology 20:620-633.

Sacks T G, Haas, H, Razin S 1969 Polyacrylamide-gel electrophoresis of cell proteins of enterobacteriaceae. A possible taxonomic aid. Israel Journal of Medical Sciences 5:49-55.

Tabaqchali S, Holland D, O'Farrell S, Silman R 1984 Typing scheme for Clostridium difficile: its application in clinical and epidemiological studies. Lancet 1:935-938.

Towbin H, Staehelin T, Gordon J 1979 Electrophoretic transfer of proteins from polyacrylamide gels to nitrocellulose sheets: procedure and some applications. Proceedings of the National Academy of Sciences of the USA 76:4350-4354. 